by other authors, to whom appropriate references aro quoted. This little monograph is to be commended. It is the first of a series which it is the intention of the publishers to issue from time to time on various aspects of surface chemistry.

\section{A Fresh Approach to the Problem of Allergy}

G. B. West and J. M. Harris of the Department of Pharmacology, School of Pharmacy, University of London, have shown that rats secured from one Wistar albino colony are resistant to the first injection of dextran or eggwhite, and that they fail to develop gross oedema of the extremitios (the so-called anaphylactoid roaction) (Ann. N.Y. Acad. Sci., 118, Article 8: Pharmacogenetics - a Fresh A pproach to the Problem of Allergy. Pp. 439 452. New York: New York Acrdemy of Sciences, 1964). Selective breeding experiments showed, first, that this non-reactivity is an autosomal recessive character, and secondly, that it is not linked with the colour genes for black or yellow. Pure stocks of non-reactor rats were establishod for both albino and non-albino strains, confirming that the anaphylactoid reaction is genetically controlled. Egg-white allergy in man is also partly inherited and also produces severe oodema of the exposed parts. It will be important, therefore, to determine the cause of non-reactivity of rats to egg-white and dextran, particularly as some genetical polymorphisms in man are known to produce biochemical differences.

\section{Soil and Landscape at Archaeological Sites}

IT is not unusual for the pedologist to be concerned in the study of former occupation sites, and an interesting paper on the examination of soil profiles, and a suggested chronology of ovents in such a neighbourhood, has been propared by P. H. Walker (Records of the Australian Museum, 26, No. 7; June 12, 1964: Soil and Landscape History in the Vicinity of Archaeological Sites at Glen Davis, New South Wales. Pp. 247-264+ plates 25-27. Sydney: The Australian Museum, 1964. 6s.). The sites are in shelters formed from large erratic sandstone boulders on the lower slopes of the Capertree River Valley, Australia, where they are characterized by several hundred feet of intensively woatherod coarse sandstone talus with narrow terraces. The debris on the upslope side of boulders reveals the past movement of the superficial deposits. The country roek is highly quartzose Triassic sandstone displaying strong current bedding. The deposits of the cave floors are relatively uniform and unstratified, and contain fow rock fragments in comparison with the soil outside; but, according to modal particle size, are derived from the sandstone rock, are less sorted than the river deposits and have arisen from the deposition of coarse material in a sheltered position. Artefacts are found in the loose, sandy layers of the soil, which is unique in the locality. The soils inside and outside the eaves are, however, to be regarded as minor surface disturbances of short duration in the development of the valley.

\section{Gairdner Foundation Awards}

THE 1965 Gairdner Foundation annual awards, valued at 5,000 dollars, have recently been awarded to: Dr. Charles P. LeBlond, head of the Department of Anatomy, McGill University, Montreal, for devolopment of the technique of autoradiography; Dr. Jerome W. Conn, University Hospital, Ann Arbor, Michigan, for his pioneering work on the clinical significance of aldosterone; Dr. R. R. A. Coombs, Departmont of Pathology, University of Cambridge, for his work on antibody on the surface of red blood cells; Dr. Charles E. Dent, University College Hospital, London, for his work on paper chromatography leading to the discovery of diseases caused by imbalance of amino-acids; Dr. Daniel J. McCarty, Hahnemann Medical College and Hospital, Philadolphia, for his work on the causos of gont and rheumatoid urthritis; Sir Horace Smirk. University of Otago Medical School,
Dunedin, New Zealand, for his work on the application of nerve-blocking drugs in the treatment of high blood pressuro. The Foundation was establishod in 1957 by of 5,000 dollars are bestowed on those who "have made contributions to the conquest of disease and the relief of human suffering".

\section{David Anderson-Berry Prize, 1966}

A David Anderson-Berry Meidal, together with a sum of money, will be awarded by the Couneil of the Royal Society of Edinburgh during 1966 , for recent work on the effects of X-rays and other forms of radiation on living tissues. Applications and proposals on behalf of others should be addressed to the General Secretary, Royal Society of Edinburgh, 22-24 George Street, Edinburgh 2 , from whom further information can be obtained. The closing date for applications will be March 31, 1966.

\section{Announcements}

Prof. O. V. S. Heath, at present professor of horticulture in the University of Reading and honorary director of the Unit of Flower Crop Physiology of the Agricultural Research Council, has been appointed to fill a vacancy in the membership of the Agricultural Research Couneil, which has arisen on the retirement, after ten years' service, of Sir Hans Krebs.

THE sixth seminar on "Electrochemistry" will be held at the Central Electrochemical Research Institute, Karaikudi, during December 26-29. Further information can be obtained from Dr. K. S. Rajagopalan, Central Electrochemical Research Institute, Karaikudi 3, Madras State.

Several ocemographic meetings and conferences, sponsored by the Institute of Marine Science, will be held at Miami Beach during November 11-24. Further information can be obtained from the Institute of Marine Science, University of Miami, 1 Rickenbacker Causeway, Miami 49, Florida.

As international conference on "Radiological Protection in the Industrial Use of Radioisotopes", organized by the Société Francaise de Radioprotection, will be held in Paris during December 13-15. Further information can be obtained from the Secretary General, Société Française de Radioprotection, Boîte Postale 3, Fontenay aux Roses, Seine.

THE winter meeting of the British Biophysical Society, on "The Conformation of Biological Macromolecules", will be held at Queen Elizabeth College, University of London, during December 20-22. Further information can be obtained from Prof. R. E. Burge, Department of Physics, Queen Elizabeth College, Campden Hill Road, London, W.8.

THe International Institute for Conservation is planning to hold a conference on "Chemicals in Museums: Quality, Care and Safo-handling" at the Institute of Archaeology, in the University of London, on January 27, 1966. The speakers invitod to take part will include a factory inspector, the medical adviser to the Trades Union Congress, a representative from the firm of Hopkin and Williams, and a member of the Government Laboratory. Further information can be obtained from Miss Gedye, Institute of Archaeology, 31 Gordon Street, London, W.1.

As international conference on the "Lymphatic System", sponsored, jointly by the Committee on Shock of tho National Academy of Sciences-National Resoarch Council and the Tulane University School of Medicine, will be held in New Orleans during December 12-14. Further information can be obtained from Prof. H. S. Mayerson, Department of Physiology, School of Medicine. Tulane University, New Orleans. 